\title{
Synthesis, X-Ray Structure and (Spectro)electrochemical Study of an Electrochromic Iron(II) Chlathrochelate with Tuned Redox Properties
}

\author{
Aleksey B. Burdukov, ${ }^{\mathrm{a}}{ }^{\circledR}$ Rastislav Šipoš, ${ }^{\mathrm{b}}$ Natalie V. Pervukhina, ${ }^{\mathrm{a}}$ \\ Nataliya V. Kuratieva, ${ }^{a}$ Ilia V. Eltsov, ${ }^{c}$ Mikhail A. Vershinin, ${ }^{a}$ \\ Evgenii G. Boguslavsky, ${ }^{a}$ Danila B. Kal'nyi, ${ }^{\text {a,c }}$ Sofia L. Selektor, ${ }^{d}$ \\ Alexander V. Shokurov, ${ }^{d}$ Yan Z. Voloshin, ${ }^{e}$ and Andrei A. Nefedov ${ }^{c, f}$ \\ ${ }^{a}$ Nikolaev Institute of Inorganic Chemistry SB RAS, 630090 Novosibirsk, Russia \\ blovak University of Technology, 81237 Bratislava, Slovakia \\ 'Novosibirsk State University, 630090 Novosibirsk, Russia \\ ${ }^{\mathrm{d}}$ Frumkin Institute of Physical Chemistry and Electrochemistry RAS, 199071 Moscow, Russia \\ ${ }^{\mathrm{N}}$ Nesmeyanov Institute of Organoelement Compounds RAS, 119991 Moscow, Russia \\ ${ }^{\mathrm{f}}$ Vorozhtsov Novosibirsk Institute of Organic Chemistry SB RAS, 630090 Novosibirsk, Russia \\ ${ }^{\circledR}$ Corresponding authorE-mail: lscc@niic.nsc.ru
}

\begin{abstract}
A boron-capped tris-dioximate iron(II) bis-macrocyclic clathrochelate with annulated dimethylquinoxaline heterocycle has been synthesized. The compound has been characterized with single-crystal X-ray diffraction, multinuclear NMR, $I R$, UV-vis spectrometry, CV and spectroelectrochemistry. The clathrochelate is capable of ligand-centered two-electron reversible reduction coupled with electrochromism (in solution and thin film).
\end{abstract}

Keywords: Macrocyclic compounds, clathrochelates, iron complexes, ligand reactivity, electrochromism.

\section{Синтез, строение и (спектро)электрохимическое исследование электрохромного клатрохелата железа(II) с модифицированными редокс-свойствами}

\author{
А. Б. Бурдуков ${ }_{1}{ }^{@}$ Р. Шипош, ${ }^{\text {b }}$ Н. В. Первухина, ${ }^{a}$ Н. В. Куратьева, ${ }^{a}$ И. В. Ельцов, \\ М. А. Вершинин, ${ }^{a}$ Е. Г. Богуславский, ${ }^{a}$ А. Б. Кальный, ${ }^{a, c}$ С. А. Селектор, ${ }^{d}$ \\ А. В. Шокуров, ${ }^{\text {, }}$ Я. З. Волошин, ${ }^{\text {e }}$ А. А. Нефредов ${ }^{\mathrm{c}, \mathrm{f}}$

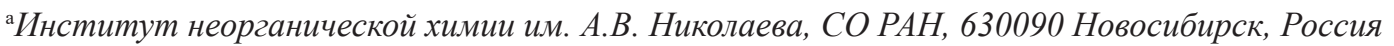
${ }^{\mathrm{b}}$ Словацкий технический университет, 81237 Братислава, Словакия

${ }^{\mathrm{c}}$ Новосибирский государственный университет, 630090 Новосибирск, Россия

${ }^{\mathrm{d}}$ Институт физической химии и электрохимии им. А.Н. Фрумкина РАН, 199071 Москва, Россия

`Институт элементоорганических соединений им. А.Н. Несмеянова РАН, 119991 Москва, Россия

${ }_{\mathrm{f}}$ Новосибирский институт органической химии им. Н.Н. Ворожиюва, СО РАН, 630090 Новосибирск, Россия

${ }^{\circledR}$ Corresponding authorE-mail: lscc@niic.nsc.ru
}

Синтезирован бор-сиитый трис-диоксиматный бис-макрочиклический клатрохелат железа(II), имеющий на ребре аннелированный диметилхиноксалиновый фрагмент. Клатрохелат способен к лиганд-иентрированному обратимому двух-электронному восстановлению сопровождаемому электрохромизмом.

Ключевые слова: Макроциклические соединения, клатрохелаты, комплексы железа, реакционная способность лиганда, электрохромизм. 


\section{Introduction}

Reactivity of the boron-capped tris-dioximate metal mono-, di-, tri-, tetra- and hexahalogenoclathrochelates have been widely used for chemical modification of their chelate ribbed fragments. These fragments of a quasiaromatic macrobicyclic polyazomethine framework have been functionalized using well-known "classical" organic reactions, such as $N, O, S, C, P$-nucleophilic substitution, ${ }^{[1-3]}$ free-radical substitution ${ }^{[4,5]}$ and electrophilic addition to the diamine iron(II) clathrochelate. ${ }^{[6,7]}$ These reactions allowed obtaining the different types of mono-, di- and triribbedfunctionalized cage complexes with pendant and annulated substitutents, thus paving the way to new types of molecular switches, ${ }^{[8]}$ wires, ${ }^{[9,10]}$ light- and redox-driven molecular machines ${ }^{[11-13]}$ and clathrochelate-based electrocatalysts for hydrogen evolution reaction. ${ }^{[14-16]}$ The rigidity of their polyazomethine macrobicyclic ligands imposes a strong limitation on the size of the encapsulated metal ion. As a result, in the most cases, only one oxidation state of this ion gives the stable cage complexes, whereas those in other oxidation states are chemically unstable and easily undergo side chemical transformations, such as the complete destruction of the clathrochelate frameworks. The only exception is cobalt clathrochelates of this type forming the stable complexes of a given encapsulating macrobicyclic ligand with an encapsulated cobalt ion in two oxidation states \{i.e. cobalt(I)/cobalt(II) or cobalt(II)/cobalt(III) pairs\}. ${ }^{[17-22]}$ Another pathway of transformations of these cage metal complexes is based on the ligand-centered processes, such as chemical or electrochemical redox reactions of heterocyclic ribbed fragments, annulated to the quasiaromatic macrobicyclic framework. Recently ${ }^{[23]}$ we reported the synthesis and reactivity of an iron(II) clathrochelate $\mathrm{FeBd}_{2}(\mathrm{QnGm})$ $(\mathrm{BF})_{2}$ (where $\mathrm{Bd}^{2-}$ and $\mathrm{Gm}$ are $\alpha$-benzildioxime dianion and glyoxime residue, respectively) carrying an annulated ribbed quinoxaline (Qn) fragment. This complex revealed the reversible, ligand-centered, chemical (electrochemical) redox transformations coupled with electrochromism. Aiming to tune the redox and electrochromic properties of such cage complexes using electron-donating (electronwithdrawing) substituents at the annulated fragment, at the first stage we chose an analogous iron(II) cage complex with two electron-donating methyl groups. Here we report the synthesis, single-crystal X-ray structure, spectral parameters, redox and (spectro)electrochemical properties of this new iron(II) clathrochelate with annulated dimethylquinoxaline ribbed fragment.

\section{Experimental}

\section{Materials}

Dichloroclathrochelate precursor $\mathrm{FeBd}_{2}\left(\mathrm{Cl}_{2} \mathrm{Gm}\right)(\mathrm{BF})_{2}$ was prepared as described in Ref. ${ }^{[24]}$ The commercial reagents (Sigma-Alrdrich ${ }^{\circledR}$ ), silica gel, 1,2-diamino-4,5-dimethylbenzene, triethylamine, tetraethylammonium perchlorate (TEAP) and organic solvents (except of DMSO and acetonitrile) were used without further purification. DMSO was dried and distilled in vacuo before the experiments. Acetonitrile was purified according to Ref. ${ }^{[25]}$

\section{Synthesis}

Complex $\mathrm{FeBd}_{2}\left(\mathrm{Cl}_{2} \mathrm{Gm}\right)(\mathrm{BF})_{2}(0.101 \mathrm{~g}, 0.14 \mathrm{mmol})$ and 1,2-diamino-4,5-dimethylbenzene $(0.024 \mathrm{~g}, 0.17 \mathrm{mmol})$ were dissolved/suspended in DMSO $(15 \mathrm{~mL})$ and few drops of triethylamine were added. The reaction mixture was intensively stirred for the dissolution of a dichloroclathrochelate precursor and left for one week. Then the reaction mixture was poured in brine $(80 \mathrm{ml})$, the precipitate formed was filtered off, dried in air, and extracted with chloroform $(150 \mathrm{ml})$. The extract was evaporated to approximately $25-30 \mathrm{ml}$, and 5-fold excess of $\mathrm{PbO}_{2}(0.7 \mathrm{mmol})$ was added to the solution. The reaction mixture was stirred for $30 \mathrm{~min}$ and then filtered. The filtrate was separated by column chromatography on silica gel (230-400 mesh; eluents: chloroform and chloroformethanol 20:1 mixture). The first elute was thrown out and the second elute was evaporated to dryness in vacuo. The solid residue was recrystallized from dichloromethane-heptane mixture and the product was dried in vacuo. Yield: $0.065 \mathrm{~g}(60 \%)$. HR ESI-MS (positive range): $\left[\mathrm{M}+\mathrm{H}^{+}\right]^{+}$: found/calculated 809.172/809.171; (negative range): $\left[\mathrm{M}-\mathrm{H}^{+}\right]^{-}$: found/calculated $-807.158 /-807.155$. ${ }^{1} \mathrm{H}$ NMR $\left(\mathrm{CD}_{2} \mathrm{Cl}_{2}\right) \delta$ ppm: $2.44\left(\mathrm{~s}, 6 \mathrm{H}, \mathrm{CH}_{3}\right), 7.26-7.5(\mathrm{~m}, 20 \mathrm{H}, \mathrm{Ph}), 7.63$ (s, 2H, Qn). ${ }^{13} \mathrm{C}\left\{{ }^{1} \mathrm{H}\right\} \operatorname{NMR}\left(\mathrm{CD}_{2} \mathrm{Cl}_{2}\right) \delta \mathrm{ppm}: 21.28\left(\mathrm{~s}, \mathrm{CH}_{3}\right), 128.56$ (s, 3-C (Ph)), 128.85 (s, CH(Qn)), 129.12 (s, 1-C (Ph)), 129.39 (s, $\left.\mathrm{C}_{\mathrm{g}}(\mathrm{Qn})\right), 130.89(\mathrm{~s}, 2-\mathrm{C}(\mathrm{Ph})), 131.18(\mathrm{~s}, 4-\mathrm{C}(\mathrm{Ph})), 147.38,147.54$, 147.78 (three $\mathrm{s}, \mathrm{C}=\mathrm{N}(\mathrm{Qn})+\mathrm{QnC}=\mathrm{N}), 157.24(\mathrm{~s}, \mathrm{PhC}=\mathrm{N}) .{ }^{11} \mathrm{~B}$ NMR $\left(\mathrm{CD}_{2} \mathrm{Cl}_{2}\right) \delta$ ppm: $4.59\left(\mathrm{~d}, J_{11_{B}{ }^{19} F}=17.3 \mathrm{~Hz}, \mathrm{O}_{3} \mathrm{BF}\right) .{ }^{19} \mathrm{~F}$ NMR $\left(\mathrm{CD}_{2} \mathrm{Cl}_{2}\right) \delta \mathrm{ppm}:-169.64$ (q, $\left.\mathrm{O}_{3} \mathrm{BF}\right)$. UV-vis $\left(\mathrm{CH}_{3} \mathrm{CN}\right) \lambda_{\max } \mathrm{nm}$ $\left(\varepsilon \cdot 10^{-3}, \mathrm{~mol}^{-1} \cdot \mathrm{L}^{-\mathrm{cm}^{-1}}\right): 420(16), 550(15), 620(23)$.

Single crystals, suitable for the X-ray diffraction experiment, were grown from dichloromethane-heptane-acetonitrile mixture.

\section{EPR Studies}

X-Band EPR spectra (modulation frequency $100 \mathrm{kHz}$ ) of in situ electrochemically generated anion-radical of the $\mathrm{FeBd}_{2}\left(\mathrm{Me}_{2} \mathrm{QnGm}\right)(\mathrm{BF})_{2}$ clathrochelate were recorded from its degassed acetonitrile solution (tetraethylammonium perchlorate [TEAP] as background electrolyte) at room temperature with a Varian E-109 spectrometer (Bruker). A home-made molybdenumglass EPR cavity with sealed-in-platinum wire electrodes was used for these combined EPR-electrochemical experiments. The EPR signal of the manganese(II) ions in $\mathrm{MgO}$ matrix was used as an external standard for calibration of the field.

\section{X-Ray Crystallography}

The intensities of reflections for the crystal $\mathrm{FeBd}_{2}\left(\mathrm{Me}_{2} \mathrm{QnGm}\right)$ (BF) $)_{2} 0.8 \mathrm{CH}_{3} \mathrm{CN}$ were measured at $298(2) \mathrm{K}$ with a Bruker Nonius $\mathrm{X} 8 \mathrm{Apex} \mathrm{CCD}$ diffractometer using graphite monochromated Mo-K $(\lambda=0.71073 \AA)$ radiation. SMART software was used for the data collection, reflection indexing and determination of the unit cell parameters. The collected data were integrated and the absorption correction was applied using SAINT ${ }^{[26]}$ software. The structure was solved by the direct method ${ }^{[27]}$ and refined by full-matrix least-squares method against $F^{2}$ for all data using SHELXTL software. ${ }^{[2]}$ Non-hydrogen atoms of the clathrochelate molecule were refined with anisotropic displacement parameters. The solvate acetonitrile molecules were refined isotropically without their hydrogen atoms with fixed occupation factors of 0.3 and 0.5 . Selected crystallographic data and refinement parameters are listed in Table 1. The structural data have been deposited to the Cambridge Structural Database (CCDC 1480832) and are available free of charge at https://summary.ccdc.cam.ac.uk/ structure-summary-form.

\section{Electrochemical Experiments}

Cyclic voltammogram (CV) of the complex $\mathrm{FeBd}_{2}\left(\mathrm{Me}_{2} \mathrm{QnGm}\right)$ $(\mathrm{BF})_{2}$ was recorded from its $1 \mathrm{mM}$ acetonitrile solution using Elins 
potentiostat $\mathrm{P}-8$ in a conventional one-compartment three-electrode cell with $0.1 \mathrm{M}$ TEAP as a supporting electrolyte. A platinum counter electrode and the $\mathrm{Ag} / 0.1 \mathrm{M} \mathrm{AgNO}_{3}$ reference electrode in acetonitrile, contacting with the solution under study through a Luggin capillary filled by the supporting electrolyte, were used. A platinum wire of $0.3 \mathrm{~mm}$-in-diameter with the geometrical surface of $0.095 \mathrm{~cm}^{2}$ was used as a working electrode. The solutions were thoroughly deaerated before the $\mathrm{CV}$ experiments using argon bubbling. All potentials are given versus saturated calomel references electrode (SCE) $(+336 \mathrm{mV}$ against the reference electrode used $\left.{ }^{[28]}\right)$. The electrochemical processes are reversible. The formal potentials $\left(E_{1 / 2}\right)$ are $-680 \mathrm{mV}$ and $-100 \mathrm{mV}$.

\section{Spectroelectrochemical Studies}

The solution spectroelectrochemical studies were carried out in a standard three-electrode configuration. Platinum mesh (the apparent surface area of $9 \mathrm{~cm}^{2}$ ) was submerged in $1 \mathrm{mM}$ acetonitrile solution of the $\mathrm{FeBd}_{2}\left(\mathrm{Me}_{2} \mathrm{QnGm}\right)(\mathrm{BF})_{2}$ clathrochelate and placed in the optic path of a fiber-optic spectrometer Avaspec2048x64 (Avantes, Netherlands) for the registration of its absorbance UV-vis spectrum in the range $300-1000 \mathrm{~nm}$. $0.1 \mathrm{M}$ tetrabutylammonium tetrafluoroborate was used as a supporting electrolyte. A platinum plate and the standard $\mathrm{Ag} / \mathrm{AgCl}$ reference electrode were used. The working and auxiliary electrodes with separate volumes were connected by a Luggin capillary.

Spectroelectrochemical studies of the cast films on mixed indium-tin oxide (ITO) electrodes were performed in an analogous three-electrode cell under similar experimental conditions, except that ITO electrode was used as the working electrode instead of platinum mesh. $0.1 \mathrm{M}$ aqueous $\mathrm{HClO}_{4}$ was used as a supporting electrolyte and $\mathrm{CV}$ measurements were performed with IPC-compact potentiostat, home-made by IPCE RAS, Russia. A platinum auxilliary electrode and the standard $\mathrm{Ag} / \mathrm{AgCl}$

\section{Results and Discussion}

Complex $\mathrm{FeBd}_{2}\left(\mathrm{Me}_{2} \mathrm{QnGm}\right)(\mathrm{BF})_{2}$ was obtained using the synthetic approach similar to that earlier elaborated for the preparation of its analog $\mathrm{FeBd}_{2}(\mathrm{QnGm})(\mathrm{BF})_{2} \cdot{ }^{[23]}$ This approach is based on nucleophilic substitution of the reactive chlorine atoms of the dichloroclathrochelate precursor $\mathrm{FeBd}_{2}\left(\mathrm{Cl}_{2} \mathrm{Gm}\right)(\mathrm{BF})_{2}$ with 4,5-dimethyl-1,2phenylenediamine in the presence of triethylamine as organic base followed by in situ oxidation of the amine macrobicyclic intermediate $\mathrm{FeBd}_{2}\left(\mathrm{H}_{2} \mathrm{QnMe}_{2} \mathrm{Gm}\right)(\mathrm{BF})_{2}$ with $\mathrm{PbO}_{2}$ (Scheme 1). The obtained $\mathrm{FeBd}_{2}\left(\mathrm{Me}_{2} \mathrm{QnGm}\right)(\mathrm{BF})_{2}$ clathrochelate was characterized using HR ESI-MS, IR, UVVis, ${ }^{1} \mathrm{H},{ }^{11} \mathrm{~B},{ }^{19} \mathrm{~F}$ and ${ }^{13} \mathrm{C}\left\{{ }^{1} \mathrm{H}\right\}$ NMR spectra. The molecular structure of this complex was studied both in solid state and in solution using single-crystal X-ray diffraction and various NMR techniques, respectively.

General view of the macrobicyclic molecule in the crystal $\mathrm{FeBd}_{2}\left(\mathrm{Me}_{2} \mathrm{QnGm}\right)(\mathrm{BF})_{2} \cdot 0.8 \mathrm{CH}_{3} \mathrm{CN}$ is shown in Figure 1. $\mathrm{FeN}_{6}$-coordination polyhedron of the encapsulated iron(II) ion possesses a geometry intermediate between a trigonal prism (the distortion angle $\varphi=0^{\circ}$ ) and a trigonal antiprism $\left(\varphi=60^{\circ}\right)$. The average $\varphi$ value of $20.5^{\circ}$, as well as the height $h$ of this polyhedron ( $2.35 \AA$ ), are characteristic of the boron-capped iron(II) tris-dioximates. ${ }^{[30]}$

$\mathrm{Fe}-\mathrm{N}$ distances in this molecule are slightly nonequivalent and fall within the range 1.917(3)-1.924(3) $\AA$ for its $\alpha$-benzildioximate fragments and are close to $1.90 \AA$ for the functionalized chelate cycle with the annulated dimethylquinoxaline heterocycle. The $\mathrm{C}-\mathrm{C}$ bonds in this heterocyclic substituent show an expressed alternation

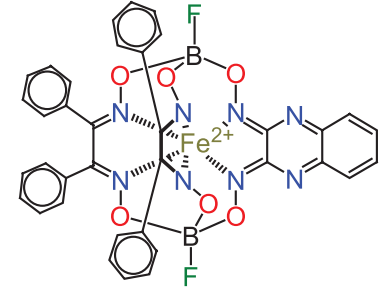

$\mathrm{FeBd}_{2}(\mathrm{QnGm})(\mathrm{BF})_{2}$

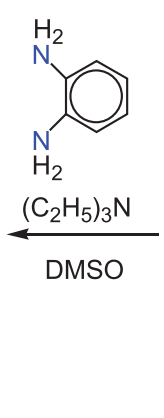

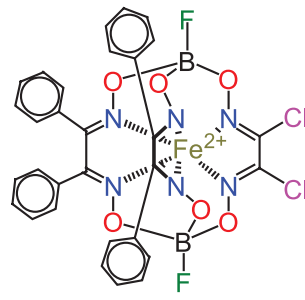

$\mathrm{FeBd}_{2}\left(\mathrm{Cl}_{2} \mathrm{Gm}\right)(\mathrm{BF})_{2}$

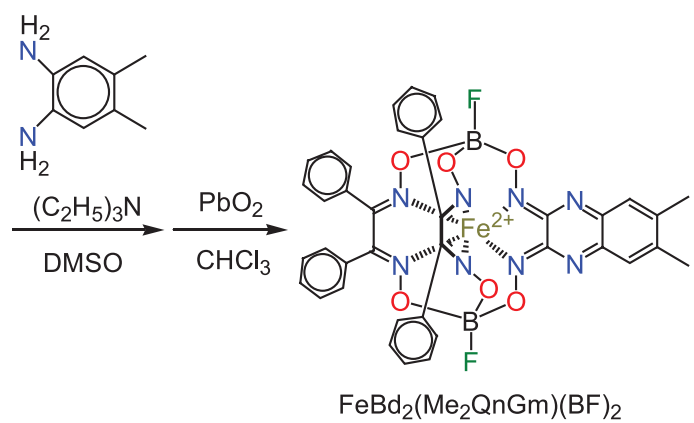

Scheme 1.

reference electrode were used. Spectroelectrochemical studies were performed in the potential range from -700 to $1000 \mathrm{mV}$; this scan range is determined by a working window of ITO electrode.

\section{NMR Experiments}

${ }^{1} \mathrm{H},{ }^{11} \mathrm{~B},{ }^{13} \mathrm{C}\left\{{ }^{1} \mathrm{H}\right\}$ and ${ }^{19} \mathrm{~F}\left\{{ }^{1} \mathrm{H}\right\}$ NMR spectra of the complex $\mathrm{FeBd}_{2}\left(\mathrm{Me}_{2} \mathrm{QnGm}\right)(\mathrm{BF})_{2}$ were recorded from its $\mathrm{CD}_{2} \mathrm{Cl}_{2}$ solution with a Bruker Avance III 500 spectrometer (working frequencies: $500.13\left({ }^{1} \mathrm{H}\right), 160.46\left({ }^{11} \mathrm{~B}\right), 470.59\left({ }^{19} \mathrm{~F}\right)$, and $\left.125.76\left({ }^{13} \mathrm{C}\right) \mathrm{MHz}\right)$. ${ }^{1} \mathrm{H}$ and ${ }^{13} \mathrm{C}\left\{{ }^{1} \mathrm{H}\right\}$ NMR chemical shifts are given in the $\delta$ scale and were referred to the signals of the solvent (5.34 ppm for $\mathrm{CHDCl}_{2}$ and $53.8 \mathrm{ppm}$ for $\mathrm{CD}_{2} \mathrm{Cl}_{2}$, respectively). Assignment of the ${ }^{1} \mathrm{H}$ and ${ }^{13} \mathrm{C}$ NMR signals for the molecule of $\mathrm{FeBd}_{2}\left(\mathrm{Me}_{2} \mathrm{QnGm}\right)(\mathrm{BF})_{2}$ was carried out using 2D HMBC and HSQC NMR techniques. ${ }^{11} \mathrm{~B}$ and ${ }^{19} \mathrm{~F}$ NMR signals of this complex were referred to $\mathrm{BF}_{3} \cdot \mathrm{O}\left(\mathrm{C}_{2} \mathrm{H}_{5}\right)_{3}$ and TFT as external standards, respectively.

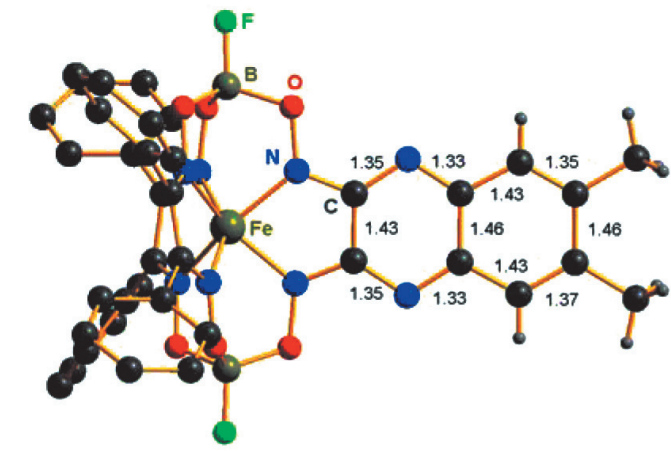

Figure 1. General view of the molecule $\mathrm{FeBd}_{2}\left(\mathrm{Me}_{2} \mathrm{QnGm}\right)(\mathrm{BF})_{2}$ with selected bond lengths. Hydrogen atoms of the phenyl substituents are omitted for clarity. 
(Figure 1) characteristic of a quinoid system. Main $\mathrm{C}=\mathrm{N}$, $\mathrm{N}-\mathrm{O}$ and $\mathrm{B}-\mathrm{O}$ bond lengths as well as the corresponding bond angles in a clathrochelate framework are characteristic of the boron-capped iron(II) tris-dioximates. ${ }^{[29,30]}$

The molecular structure of the clathrochelate $\mathrm{FeBd}_{2}\left(\mathrm{Me}_{2} \mathrm{QnGm}\right)(\mathrm{BF})_{2}$ in solution was confirmed using one-dimensional (1D) and two-dimensional (2D) ${ }^{1} \mathrm{H}$ and ${ }^{13} \mathrm{C}\left\{{ }^{1} \mathrm{H}\right\}$ NMR spectra; the assignment of the signals in these spectra is shown in Figure 2. These NMR data were found to be in an excellent agreement with the above single-crystal $\mathrm{X}$-ray diffraction data.

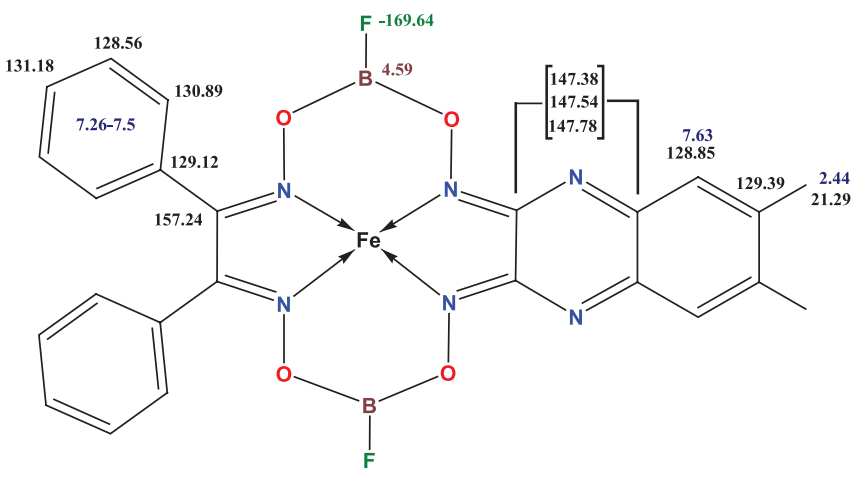

Figure 2. Assignment of the NMR signals for the molecule $\mathrm{FeBd}_{2}\left(\mathrm{Me}_{2} \mathrm{QnGm}\right)(\mathrm{BF})_{2}$.

Electrochemical and spectroelectrochemical characteristics of the complex FeBd $\left(\mathrm{Me}_{2} \mathrm{QnGm}\right)(\mathrm{BF})_{2}$ were recorded from its acetonitrile solution. Cyclic voltammogram $(\mathrm{CV})$ of this clathrochelate (Figure 3 ) in the cathodic range contains two one-electron reduction waves at the potentials $E_{2 c}=-710 \mathrm{mV}$ and $E_{1 c}=-130 \mathrm{mV}$. Backscanning of the potential showed two re-oxidation waves with the peaks at $E_{2 a}=-650 \mathrm{mV}$ and $E_{1 a}=-70 \mathrm{mV}$. The formal potentials $\left(E_{1 / 2}\right)$ are $-680 \mathrm{mV}$ and $-100 \mathrm{mV}$, correspondingly.

The differences $\Delta E=E_{i a}-E_{i c}$ between the peaks of these direct and backward processes are approximately $60 \mathrm{mV}$ and the above potentials are only slightly affected by the change of scan rate from 100 to $1200 \mathrm{mV} \cdot \mathrm{s}^{-1}$, thus suggesting the reversible character of these redox processes. ${ }^{[31]}$ In general, the electrochemical characteristics of this cage complex are quite similar to those of the $\mathrm{FeBd}_{2}(\mathrm{QnGm})(\mathrm{BF})_{2}$ clathrochelate, but in the former case these potentials are shifted by approximately $80 \mathrm{mV}$ to the cathodic range due to inductive effect of the weakly electron-donating methyl groups. First of these reduction processes gives an anion-radical

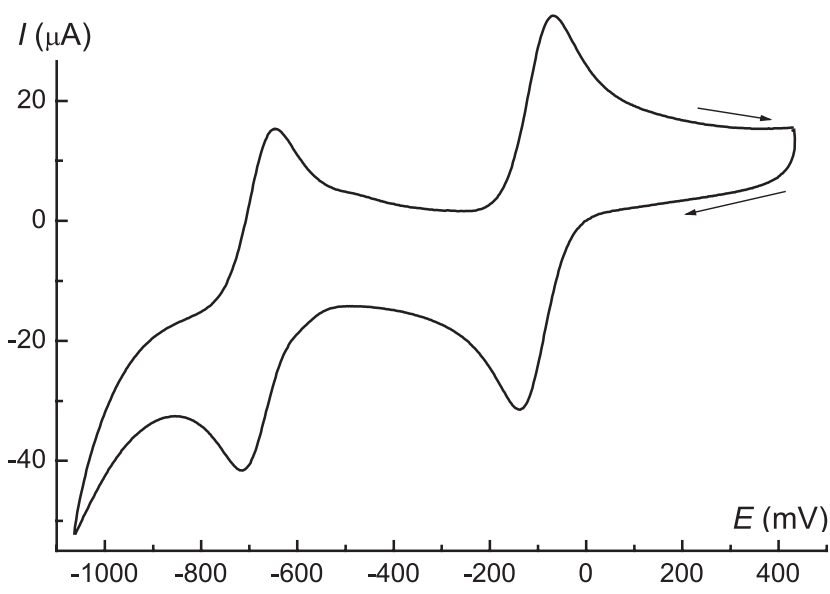

Figure 3. $\mathrm{CV}$ for $1 \mathrm{mM}$ acetonitrile solution of the complex $\mathrm{FeBd}_{2}\left(\mathrm{Me}_{2} \mathrm{QnGm}\right)(\mathrm{BF})_{2}$ at scan rate of $100 \mathrm{mV} \cdot \mathrm{s}^{-1}$.

derivative of the complex $\mathrm{FeBd}_{2}\left(\mathrm{Me}_{2} \mathrm{QnGm}\right)(\mathrm{BF})_{2}$ shown in Scheme 2.

This result was confirmed by in situ EPR experiment (Figure 4). The obtained Lande factor value of 2.004 is characteristic of the compounds with an unpaired electron localized on light atoms, thus confirming the ligand-centered character of the redox process.

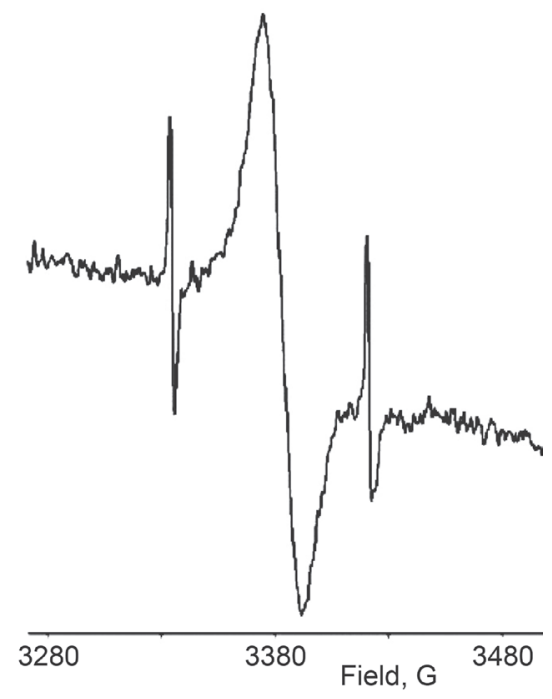

Figure 4. X-Band EPR spectrum of acetonitrile solution of in situ electrochemically generated reduced form of the clathrochelate $\mathrm{FeBd}_{2}\left(\mathrm{Me}_{2} \mathrm{QnGm}\right)(\mathrm{BF})_{2}$. The sharp signals correspond to the manganese(II) ions as an external standard.

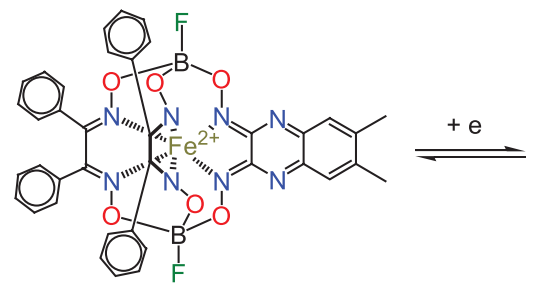

$\mathrm{FeBd}_{2}\left(\mathrm{Me}_{2} \mathrm{QnGm}\right)(\mathrm{BF})_{2}$

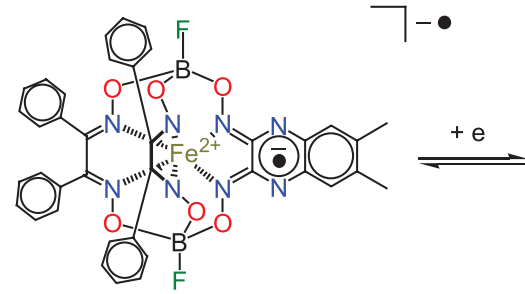

$\left[\mathrm{FeBd}_{2}\left(\mathrm{Me}_{2} \mathrm{QnGm}\right)(\mathrm{BF})_{2}\right]^{-} \bullet$

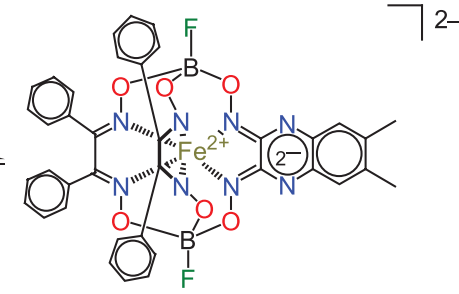

$\left[\mathrm{FeBd}_{2}\left(\mathrm{Me}_{2} \mathrm{QnGm}\right)(\mathrm{BF})_{2}\right]^{2-}$

Scheme 2. 
Two major bands with maxima at approximately 415 and $610 \mathrm{~nm}$ (Figure 5) cause blue coloration of an acetonitrile solution of the $\mathrm{FeBd}_{2}\left(\mathrm{Me}_{2} \mathrm{QnGm}\right)(\mathrm{BF})_{2}$ complex. Its chemical reduction with metallic lithium proceeded rather slow being completed in approximately $2.5 \mathrm{~h}$ and gave a red solution; its coloration is determined by superposition of new bands with maxima at $390,475,510$, and $708 \mathrm{~nm}$. The presence of the corresponding isobestic points suggests the stoichiometric character of this reduction process. UV-vis spectrum of the obtained reduced form of $\mathrm{FeBd}_{2}\left(\mathrm{Me}_{2} \mathrm{QnGm}\right)$ $(\mathrm{BF})_{2}$ is very similar to that of the radical anion derivative of the clathrochelate $\mathrm{FeBd}_{2}(\mathrm{QnGm})(\mathrm{BF})_{2} \cdot{ }^{\left[{ }^{[23]}\right.}$

The similar spectral changes were spectroelectrochemically observed in the course of an electrochemical reduction of $\mathrm{FeBd}_{2}\left(\mathrm{Me}_{2} \mathrm{QnGm}\right)(\mathrm{BF})_{2}$ : the absorption band with maximum at approximately $600 \mathrm{~nm}$ goes down, whereas new bands with maxima from 450 to $500 \mathrm{~nm}$ appear (Figure 6).

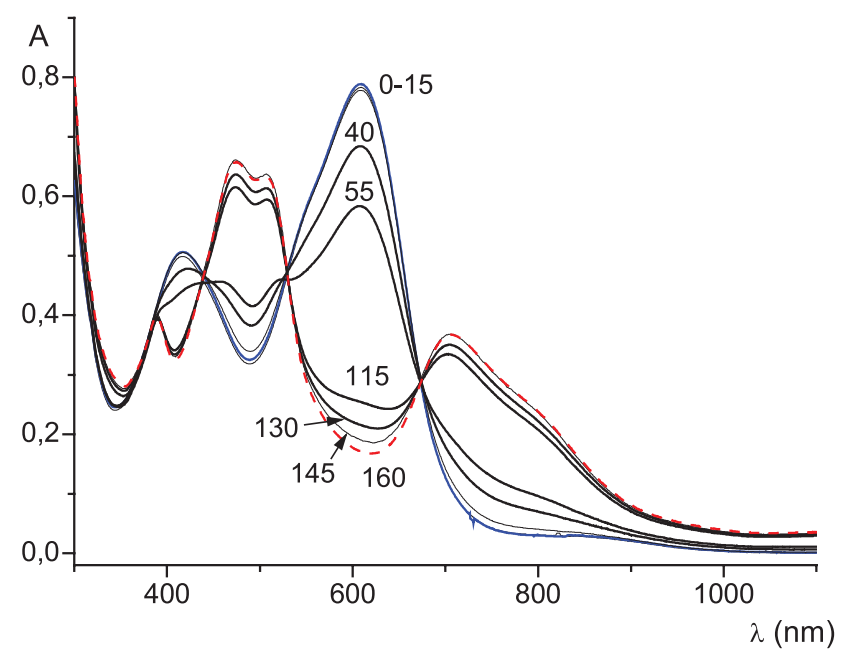

Figure 5. UV-vis spectra of acetonitrile solution of the $\mathrm{FeBd}_{2}\left(\mathrm{Me}_{2} \mathrm{QnGm}\right)(\mathrm{BF})_{2}$ clathrochelate $\left(c=3.1 \cdot 10^{-5} \mathrm{~mol} \cdot \mathrm{L}^{-1}\right)$ during its reduction with metallic lithium; the total reaction time is 160 mins (start: in blue, end: in dashed red line).

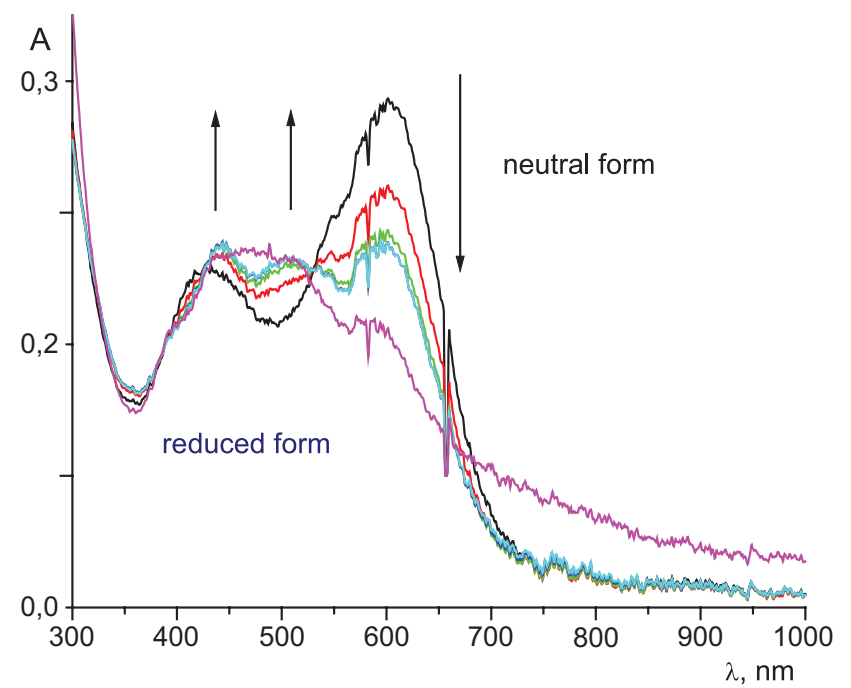

Figure 6. UV-vis spectra of acetonitrile solution of the clathrochelate $\mathrm{FeBd}_{2}\left(\mathrm{Me}_{2} \mathrm{QnGm}\right)(\mathrm{BF})_{2}\left(c=1.0 \cdot 10^{-5} \mathrm{~mol} \cdot \mathrm{L}^{-1}\right)$ upon application of the redox potential from $+400 \mathrm{mV}$ (the initial complex) to $-1200 \mathrm{mV}$ (its reduced form).
Surprisingly, we failed to observe any optical response from the second reduction of $\mathrm{FeBd}_{2}\left(\mathrm{Me}_{2} \mathrm{QnGm}\right)(\mathrm{BF})_{2}$ after either chemical or electrochemical reduction. This result contrasts with that for its homolog $\mathrm{FeBd}_{2}(\mathrm{QnGm})(\mathrm{BF})_{2}$, where both reduced forms (i.e. radical anion and dianion species) have been clearly detected ${ }^{[23]}$ using the same technique; the origin of this difference requires additional studies.

The reduction of the $\mathrm{FeBd}_{2}\left(\mathrm{Me}_{2} \mathrm{QnGm}\right)(\mathrm{BF})_{2}$ clathrochelate was also examined in a cast film. Due to limitations of the electrochemical window of the working ITO electrode, the potentials above $-700 \mathrm{mV}$ (vs. $\mathrm{Ag} / \mathrm{AgCl})$, corresponding to the first reduction process, were applied. Changes of the differential UV-vis spectra of this film (with the spectrum of the initial complex as a baseline) are shown in Figure 7. It is clearly seen that the absorption bands with maxima at approximately 420 and $500 \mathrm{~nm}$ increase simultaneously with rising degree of reduction. This electrochromic transition $\mathrm{FeBd}_{2}\left(\mathrm{Me}_{2} \mathrm{QnGm}\right)(\mathrm{BF})_{2} \rightarrow\left[\mathrm{FeBd}_{2}\left(\mathrm{Me}_{2} \mathrm{QnGm}\right)(\mathrm{BF})_{2}\right]^{-\bullet}$ can be easily detected with naked eye (Figure 8 ). Unexpectedly, this spectrum also showed some changes in the NIR range from 900 to $1000 \mathrm{~nm}$.

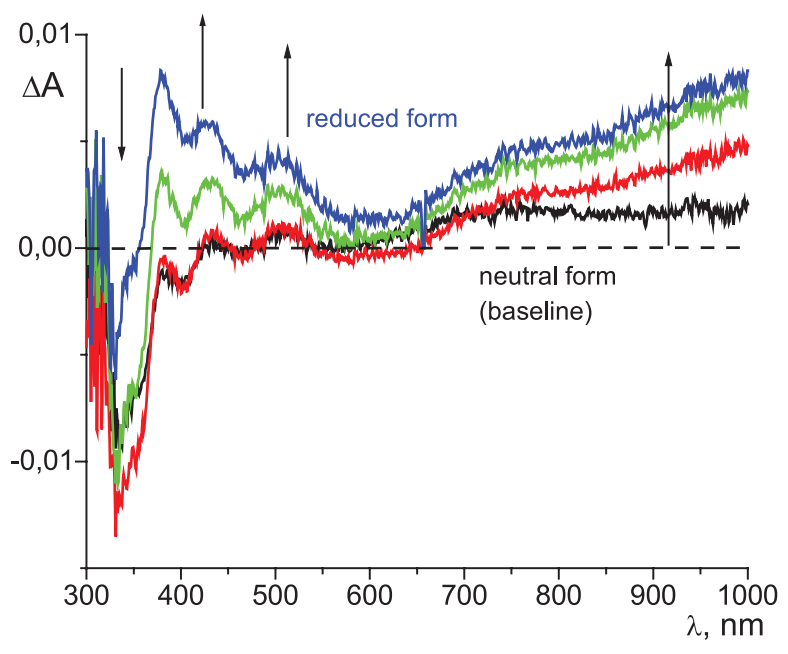

Figure 7. Differential UV-vis absorption spectra of the reduced forms of the clathrochelate $\mathrm{FeBd}_{2}\left(\mathrm{Me}_{2} \mathrm{QnGm}\right)(\mathrm{BF})_{2}$ in a cast film (with the spectrum of an initial cage complex as a baseline) upon application of the redox potential from +400 (an initial complex) to $-700 \mathrm{mV}$ (its one-electron reduced form).

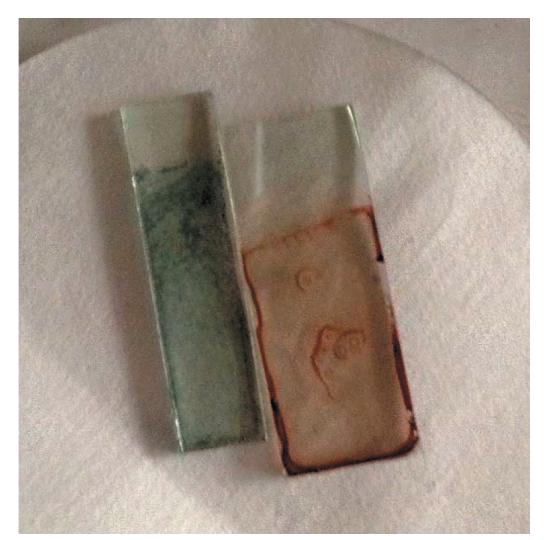

Figure 8. Photography of the cast films of the initial clathrochelate $\mathrm{FeBd}_{2}\left(\mathrm{Me}_{2} \mathrm{QnGm}\right)(\mathrm{BF})_{2}$ (on the left) and its reduced radical anion form (on the right). 


\section{Conclusions}

Comparison of a monoribbed-functionalized iron(II) clathrochelate with annulated dimethyl substituted quinoxaline fragment and its non-methylated analog showed that these distal substituents allow fine tuning of the potential of their ligands-centered redox processes.

Acknowledgements. The authors gratefully acknowledge support of the RFBR (grant 16-03-00408). Y.Z.V. also thanks the Russian Science Foundation (project 16-13-10475) for the financial support of the synthetic part of this work.

Table 1. Crystallographic data and refinement parameters for the crystal $\mathrm{FeBd}_{2}\left(\mathrm{Me}_{2} \mathrm{QnGm}\right)(\mathrm{BF})_{2} \cdot 0.8 \mathrm{CH}_{3} \mathrm{CN}$.

\begin{tabular}{ll}
\hline Empirical formula & $\mathrm{C}_{39.6} \mathrm{H}_{28} \mathrm{~B}_{2} \mathrm{~F}_{2} \mathrm{FeN}_{8.8} \mathrm{O}_{6}$ \\
Formula weight & 838.58 \\
Temperature $(\mathrm{K})$ & $293(2)$ \\
Wavelength $(\AA)$ & 0.71073 \\
Crystal system & monoclinic \\
Space group & $C 2 / \mathrm{c}$ \\
$a(\AA)$ & $33.502(1)$ \\
$b(\AA)$ & $16.735(1)$ \\
$c(\AA)$ & $15.589(1)$ \\
$\beta\left({ }^{\circ}\right)$ & $107.33(1)$ \\
Volume $\left(\AA^{3}\right)$ & $8343.5(6)$ \\
$\mathrm{Z}$ & 8 \\
Density (calculated) $\left(\mathrm{g} \cdot \mathrm{cm}^{-3}\right)$ & 1.328 \\
Absorption coefficient $\left(\mathrm{mm}^{-1}\right)$ & 0.425 \\
$\mathrm{~F}(000)$ & 3424 \\
Crystal size (mm) & $0.35 \times 0.16 \times 0.08$ \\
Theta range for data collection & $2.27-26.43^{\circ}$ \\
Index ranges & $-41 \leq \mathrm{h} \leq 37,-20 \leq \mathrm{k} \leq 20$, \\
Reflections collected & $-19 \leq 1 \leq 19$ \\
Independent reflections & 30664 \\
Completeness to theta $=25.00^{\circ}(\%)$ & $8498\left(\mathrm{R}_{\text {int }}=0.0500\right)$ \\
Data / restraints / parameters & 99.3 \\
Goodness-of-fit on $\mathrm{F}^{2}$ & $8498 / 0 / 522$ \\
Final R indices $\left(\mathrm{I}>2 \sigma_{\mathrm{I}}\right)$ & 0.951 \\
$\mathrm{R}$ indices (all data) & $\mathrm{R}_{1}=0.0568, \mathrm{wR}_{2}=0.1672$ \\
Largest diff. peak and hole $\left(\mathrm{e} / \AA^{-3}\right)$ & 0.982 and -0.290 \\
\hline &
\end{tabular}

\section{References}

1. Voloshin Y.Z., Belaya I.G., Belov A.S., et al. Dalton. Trans. 2012, 41, 737-746 and references therein.

2. Artyushin O.I., Odinets I.L., Matveeva E.V., et al. Dalton Trans. 2014, 43, 9677-9689.

3. Artyushin O.I., Matveeva E.V., Vologzhanina A.V., Voloshin Y.Z. Dalton Trans. 2016, 45, 5328-5333

4. Vershinin M.A., Burdukov A.B., Eltsov I.V., et al. Polyhedron 2011, 30, 1233-1237.

5. Burdukov A.B., Vershinin M.A., Boguslavsky E.G., et al. Inorg. Chem. Commun. 2013, 36, 117-121.
6. Vershinin M.A., Burdukov A.B., Boguslavskii E.G., et al. Inorg. Chim. Acta 2011, 366, 91-97.

7. Burdukov A.B., Šipoš R., Vershinin M.A., Pervukhina N.V., Kuratieva N.V., Plyusnin P.E., Eltsov I.V., Voloshin Ya.Z. J. Coord. Chem. 2015, 68, 3894-3902.

8. Viswanathan S., Voloshin Y.Z., Radecka H., Radecki J. Electrochim. Acta 2009, 54(23), 5431-5438.

9. Liu W., Huang W., Pink M., Lee D. J. Am. Chem. Soc. 2010, 132, 11844-11846.

10. Liu W., Huang W., Chen C.-H., Pink M., Lee D. Chem. Mater. 2012, 24, 3650-3658.

11. Voloshin Y.Z., Varzatskii O.A., Antipin M.Y., Korobko S.V., Chernii V.Y., Volkov S.V., Pehn'o V.I., Starikova Z.A. Inorg, Chem. 2005, 44, 822-824.

12. Voloshin Y.Z., Varzatskii O.A., Belov A.S., Starikova Z.A., Suponitsky K.Y., Novikov V.V., Bubnov Y.N. Inorg.Chem. 2008, 47, 2155-2161.

13. Sabin J.R., Varzatskii O.A., Voloshin Y.Z., Starikova Z.A., Novikov V.V., Nemykin V.N. Inorg. Chem. 2012, 51, 8362-8372.

14. Voloshin Y.Z., Dolganov A.V., Varzatskii O.A., Bubnov Y.N. Chem. Commun. 2011, 47, 7737-7739.

15. Voloshin Y.Z., Belov A.S., Vologzhanina A.V., Aleksandrov G.G., Dolganov A.V., Novikov V.V., Varzatskii O.A., Bubnov Y.N. Dalton Trans. 2012, 6078-6093.

16. Dolganov A.V., Belov A.S., Novikov V.V., Vologzhanina A.V., Mokhir A., Bubnov Y.N., Voloshin Y.Z. Dalton Trans. 2013, 4373-4376.

17. Boston D.R., Rose N.J. J. Am. Chem. Soc. 1973, 95, 4163-4168.

18. Voloshin Y.Z., Nazarenko A.Yu., Pol'shin E.V., Tyukhtenko S.I., Kostromina N.A. Theor. Exp. Chem. 1989, 25, 298-303.

19. Voloshin Y.Z., Kostromina N.A., Nazarenko A.Y. Theor. Exp. Chem. 1990, 26, 352-354.

20. Murguia M.A., Borchardt D., Wherland S. Inorg. Chem. 1990, 29, 1982-1986.

21. Voloshin Y.Z., Varzatskii O.A., Vorontsov I.I., Antipin M.Y. Angew. Chem., Int. Ed. 2005, 44, 3400-3402.

22. Voloshin Y.Z., Varzatskii O.A., Novikov V.V., Strizhakova N.G., Vorontsov I.I., Vologzhanina A.V., Lyssenko K.A., Romanenko G.V., Fedin M.V., Ovcharenko V.I., Bubnov Y.N. Eur. J. Inorg. Chem. 2010, 5401-5415.

23. Burdukov A.B., Vershinin M.A., Pervukhina N.V., et al. Inorg. Chem. Commun. 2014, 44, 183-187.

24. Voloshin Y.Z., Zavodnik V.E., Varzatskii O.A., Belsky V.K., Palchik A.V., Strizhakova N.G., Vorontsov I.I., Antipin M.Y. Dalton Trans. 2002, 1193-1202.

25. Armarego W.L.F., Chai C. Purification of Laboratory Chemicals, Oxford: Butterworth-Heinemann, 6th ed., 2009. $609 \mathrm{p}$.

26. Bruker AXS Inc. (2004). APEX2 (Version 1.08), SAINT (Version 7.03), and SADABS (Version 2.11). Bruker Advanced $\mathrm{X}$-Ray Solutions, Madison, Wisconsin, USA.

27. Burla M.C., Caliandro R., Camalli M., Carrozzini B., Cascarano G.L., De Caro L., Giacovazzo C., Polidori G., Spagna R. J. Appl. Cryst. 2005, 38, 381-388.

28. Sheldrick G.M. SHELXS97 and SHELXL97. Programs for the Refinement of Crystal Structures. University of Göttingen, Germany, 1997.

29. Larson R.C., Iwamoto R.T., Adams R.N. Anal. Chim. Acta 1961, 25(1), 371-374.

30. Voloshin Y.Z., Antipin M.Yu. Russ. Chem. Bull., Int. Ed. 2004, 53, 2097-2108 (a review).

31. Bard A.J., Faulkner L.R. Electrochemical Methods. Fundamentals and Applications, New York: Wiley, 2nd ed., 2001. 864 p. 